\title{
Unrepairable substrates of nucleotide excision repair and their application to suppress the activity of this repair system
}

\author{
A. A. Popov ${ }^{1}$, A. N. Evdokimov ${ }^{1}$, N. V. Lukyanchikova ${ }^{1}$, I. O. Petruseva ${ }^{1}$, O. I. Lavrik ${ }^{1,2}$ \\ ${ }^{1}$ Novosibirsk Institute of Chemical Biology and Fundamental Medicine, \\ Siberian Branch of the Russian Academy of Sciences \\ 8, Akademika Lavrentieva Ave., Novosibirsk, Russian Federation, 630090 \\ ${ }^{2}$ Novosibirsk State University \\ 2, Pirogova Str., Novosibirsk, Russian Federation, 630090 \\ lavrik@niboch.nsc.ru
}

In the previous studies, the DNA with the bulky Fap-dC derivative was demonstrated to be a difficult substrate for the nucleotide excision repair (NER), a system which is involved in the removal of bulky lesions from DNA. This type of compounds could be of particular interest as possible selective NER, considerably reducing the potency of DNA repair due to competitive immobilization of protein factors involved in this process. This approach can be potentially useful to increase the efficiency of chemotherapy. Aim. To identify DNA structures containing multiple bulky adducts that can efficiently inhibit the nucleotide excision repair. Methods. Enzymatic DNA synthesis, PCR, NER-competent cell extract preparation, in vitro NER assay, HPLC. Results. The conditions for the synthesis of extended DNA containing multiple unrepairable lesions were established. A wide range of DNA structures containing modified nucleotides was obtained. All modified DNAs were shown to inhibit the in vitro activity of the NER system. The DNA structure that inhibits the NER activity with the highest efficiency was selected. Conclusions. The model DNA structures effectively inhibiting the activity of NER were found. The new data obtained here can potentially be used for both basic and applied research.

Ke y w o r d s: DNA repair, nucleotide excision repair, unrepairable DNA lesions, model DNA substrates

\section{Introduction}

The nucleotide excision repair system (NER) removes from the DNA a wide range of bulky adducts that are induced into DNA by ultraviolet light (UV), various chemically active compounds (drugs, mutagenic environmental compounds), active forms of oxygen and ionizing radiation [1]. The damages removed by the NER system include the products of photocrosslinking of adjacent pyrimidine bases, platinum adducts, protein-DNA crosslinking;

(C) 2019 A. Popov et al.; Published by the Institute of Molecular Biology and Genetics, NAS of Ukraine on behalf of Biopolymers and Cell. This is an Open Access article distributed under the terms of the Creative Commons Attribution License (http://creativecommons.org/licenses/by/4.0/), which permits unrestricted reuse, distribution, and reproduction in any medium, provided the original work is properly cited 
adducts arising from the interaction of active derivatives of benzo[a]pyrene, benzo[c]anthracene, acetylaminofluorene with DNA, as well as with other bulky adducts, significantly disturbing the regular structure of double-stranded DNA [2].

About 30 proteins are involved in the NER process, forming functional complexes at each stage of the reparative process $[1,3]$. These proteins carry out the search for damage, its verification and subsequent removal of short oligonucleotide containing the lesion. The resynthesis of the nucleotide sequence is performed by the specialized DNA repair polymerases and several proteins of the DNA replication.

One of the approaches to the study of NER mechanism includes the use of the synthetic substrate analogues - double-stranded DNAs containing bulky modification in the defined position of a molecule, as well as structural analogs of the intermediates of NER process [4-9]. The model DNAs mimicking various NER intermediates can be used as a tool for determining the parameters of protein affinity to damaged DNA $[10,11]$. The extended linear DNA duplexes can be also used to study the stage of damage elimination and the changes of protein-DNA complexes that occur in the NER process. Thus, the substrates with bulky groups, which are highly recognized and removed from the DNA by the NER system, can serve as a tool for determining the activity of this system in vitro [12].

The model DNAs containing photoactivatable or chemically active groups are of great interest, as it can be regarded as the probes for affinity modification of proteins [13]. Various DNA derivatives containing arylazido groups have been used most widely to design photoactivatable DNA probes. Their rapid activation by exposure to UV light after the formation of a complex of photoreactive substrate with the protein makes it possible to study the dynamics of the process of proteinDNA interactions in NER [14]. For instance new details of the mechanism of primary damage recognition during the NER process were estimated using photoactivatable analogs of the NER substrates. The method of photoaffinity modification was used to determine a character of protein-DNA interactions for the main proteins involved in the recognition and verification of the damage - XPC, RPA and XPA [10, 15-17].

Among the previously used photoactivable model DNAs, the 4-azido-2,5-difluoro-3-chloropyridin-6-yl derivative of $\mathrm{dC}($ Fap-dC) is of particular interest. It was shown that Fap-dC in the DNA duplex with a length of $137 \mathrm{bp}$ is a practically unrepairable damage for the NER system [18]. At the same time, DNA containing Fap-dC can efficiently bind [the] NER factors $[19,20]$. Fap-dC demonstrated a high efficiency as a probe for [the] photoaffinity modification of DNA binding proteins in [the] NERcompetent HeLa cell extracts $[11,18]$. Thus, DNA of various lengths and structures containing Fap-dC residue at the defined position was successfully used to study the NER system.

The extended model DNA structures containing reactive and hardly repairable damage can serve as a useful tool for comparative assessments of the ability to suppress NER, as well as for investigations which include visualization of nucleoprotein complexes. The purpose of this work was to obtain extended model DNAs containing multiple Fap-dC 
groups, and to analyze the possible use of such DNAs to suppress the activity of the NER system.

\section{Materials and Methods}

T4-polynucleotide kinase, T4-DNA ligase and Taq DNA polymerase were from "Biosan" (Novosibirsk); DNA polymerase $\beta$ was kindly provided by S. N. Khodyreva; the set of the enzymes for DNA digestion "DNA Degradase" was produced by "ZymoResearch"; $a-\left[{ }^{32} \mathrm{P}\right]-$ $\mathrm{dCTP}$ and $\mathrm{\gamma}-\left[{ }^{32} \mathrm{P}\right]$-ATP $(3000 \mathrm{Ci} / \mathrm{mmol})$ were produced at ICBFM SB RAS; Fap-dCTP (Fig. 1A) was synthesized as described in [21] and kindly provided by I. V. Safronov; oligodeoxyribonucleotide containing non-nucleoside insertion nAnt (ONT-1, Table 1; Fig. 1B) was synthesized as described in [12]; C33A (human cervical cancer cell line) cells were kindly provided by N. P. and F L. Kisselev. Furthermore, proteinase K, dNTP's ("Biosan", Novosibirsk), urea, N,N'-methylenbisacrilamide ("Amersco"), acrilamide ("Applichem"), TEMED ("Helicon"), DEAE filters DE-81 ("Whatman"), DNA Gel Extraction Kit QIAquick ("Qiagen"), Quick Start Bradford Protein Assay Kit ("Biorad") were used in this work.

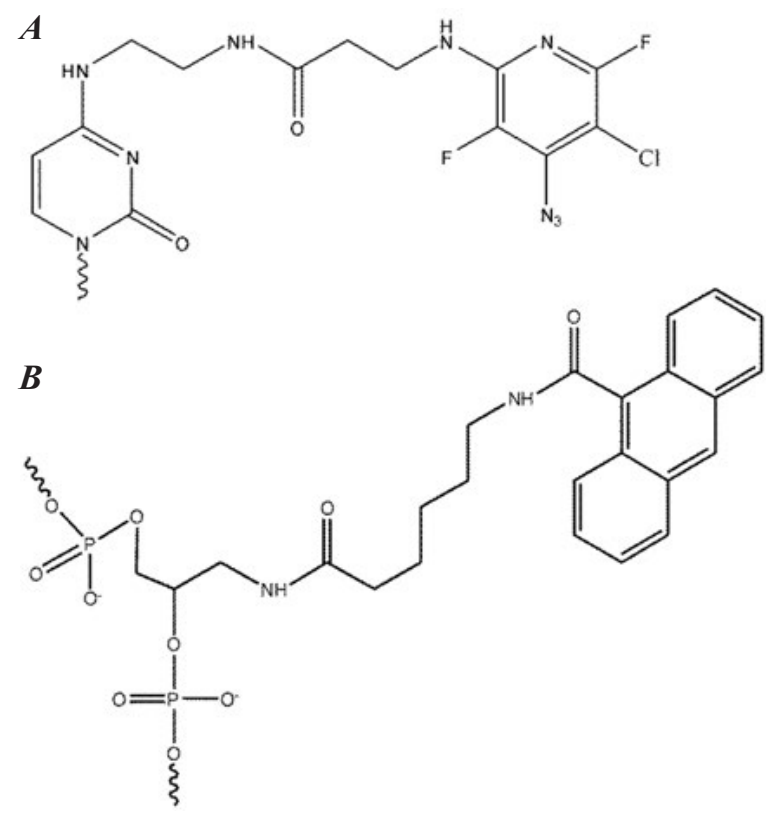

Fig. 1. Structures of model lesion used. Exo- $N-\{2-[N-(4-$ azido-2,5-difluoro-3-chloropyridin-6-yl)-3-aminopropionyl] aminoethyl -deoxycytidinine (Fap-dC, A) and the nonnucleoside fragment of the modified DNA strand, containing $\mathrm{N}$-[6-(9-antracenylcarbomoyl)hexanoyl]-3-amino-1,2propandiol (nAnt, B)].

The sequences of the oligodeoxyribonucleotides (ONT) used are shown in Table 1.

Synthesis of 137-nt DNA duplex containing non-nucleoside insertion $n A n t$. ONT-1 containing non-nucleoside fragment with $N$-[6-(9-

Table 1. The numbering, sequence and length of oligonucleotides (ONT) used.

\begin{tabular}{|c|c|c|}
\hline ONT \# & Sequence & length, nt \\
\hline 1 & 5'-caccgtcMccctggat* & 16 \\
\hline 2 & 5'-caccgtcgecctggat & 16 \\
\hline 3 & 5'-tggacgatatcccgcaagaggcccggcagtaccggcataaccaagcctatgcctacagcatccaggg & 67 \\
\hline 4 & 5'-gacggtgccgaggatgacgatgagcgcattgttagatttcatacacggtgcctgactgcgttagcaatt & 69 \\
\hline 5 & 5'-gcctacagcatccagggcgacggtgccgaggatg & 34 \\
\hline 6 & 5'-atcaccggcgccaca & 15 \\
\hline 7 & 5'-gtatccgctcatgagacaat & 20 \\
\hline 8 & 5'-gggggctcggcaccgtcaccctggatgctgtagg & 34 \\
\hline
\end{tabular}

*M - non-nucleoside insertion nAnt. 
antracenylcarbomoyl)hexanoyl]-3-amino-1,2propandiol (nAnt), flanking 5'-[ $\left.{ }^{32} \mathrm{P}\right]-\mathrm{ONT}-3$ and ONT-4 were mixed with template ONT-5 in equimolar amount. The mixture was heated at $95^{\circ} \mathrm{C}$ for $5 \mathrm{~min}$, than slowly cooled (about of $1^{\circ} \mathrm{C}$ per minute) to the room temperature. The ligation of the single strand breaks was carried out by the addition of T4 DNA ligase and ATP with the following incubation at $12^{\circ} \mathrm{C}$ for $12 \mathrm{~h}$. Single-stranded DNA obtained was purified by electrophoresis in polyacrylamide gel under denaturing conditions according to [22]. Briefly, the target DNA was separated by electrophoresis and was isolated from gel by electroelution to DEAE filter. The elution of oligonucleotide from DEAE filter was performed at $70^{\circ} \mathrm{C}$ by $3 \mathrm{M} \mathrm{LiClO}_{4}$. DNA was precipitated with acetone and dissolved in TE buffer. The resulting modified DNA was annealed with the appropriate complementary strand.

Synthesis of 756-nt DNA by PCR. Nonmodified 756 bp DNA was obtained by PCR using pBR322 as template and ONT-6 and ONT-7 as primers. The $100 \mu \mathrm{l}$ of reaction mixture contained $25 \mathrm{ng}$ of a template, $0.5 \mu \mathrm{M}$ primers, $0.2 \mathrm{mM}$ dNTP's, $1.5 \mathrm{mM} \mathrm{MgCl}$ and 6 units of Taq DNA polymerase in Taq DNA polymerase reaction buffer. In order to obtain the modified DNA of the same length, PCR was carried out under the same conditions with addition of 5 to $160 \mu \mathrm{M}$ Fap-dCTP in the reaction mixture. $\mathrm{PCR}$ products were precipitated with ethanol in $0.3 \mathrm{M} \mathrm{CH}_{3} \mathrm{COONa}(\mathrm{pH} 5.5)$ with linear polyacrylamide as a co-precipitant and then dissolved in TE buffer. Purification of PCR products was carried out by electrophoresis in $1 \%$ agarose gel. Isolation of DNA from agarose gel was performed using
QIAquick Kit ("Qiagen") according to protocol provided by manufacturer.

Resulting DNAs concentrations were determined by measuring the optical density of the solution at $260 \mathrm{nM}$. The concentration of DNA obtained was calculated using "OligoCalculator".

NER-competent C33A cell extract was obtained by the standard method described in [23]. The concentration of protein in the extract was determined using Quick Start Bradford Protein Assay Kit ("Bio Rad"), using BSA as a standard for the calibration curve.

Analysis of relative NER efficiency was carried out by the method described in [12] using 137 bp DNA containing nAnt lesion, and ONT-8 as a template for detection of the excision products. Briefly, the excision products were detected by annealing to the template followed by end-labeling using $\alpha-\left[{ }^{32} \mathrm{P}\right]$-dCTP and Taq DNA polymerase. The analysis of the excision products was performed by electrophoresis in $10 \%$ polyacrilamide under denaturating conditions. Mixture of $\left[{ }^{32} \mathrm{P}\right]-5$ '-labeled oligodeoxyribonucleotides was used as a DNA ladder. To estimate the influence of $756 \mathrm{bp}$ Fap-dC- and non-modified DNA on specific excision of nAnt lesion from the model DNA the extended DNA was added into reaction mixtures during the excision reaction.

Enzymatic hydrolysis of 756-strand DNA to deoxymononucleotides was performed using the DNA Degradase kit (“Zymo Researsh") according to the manufacturer's protocol.

Analysis of a mixture of mononucleotides was performed using high performance liquid chromatography (HPLC) with chromatograph Milichrom A-02 and ProntoSIL-120-5-C18 AQ column. Gradient from $0 \%$ acetonitrile in 0.05 triethylamine acetate (TEEAAc) to $100 \%$ 
acetonitrile in 0.05 TEEAAc was used at $\mathrm{pH}$ 7.5, $40^{\circ} \mathrm{C}, 0.15 \mathrm{ml} / \mathrm{min}$ and $3.9 \mathrm{MPa}$.

\section{Results and Discussion}

Synthesis of $756 \mathrm{bp}$ DNA duplexes was performed using PCR. To ensure the specificity and productivity of the synthesis of the target product, the conditions for PCR were optimized: the time of each stage of the cycle was determined, the optimal composition of the buffer, the concentration of dNTP and primers were selected.

A modified analogue of nitrogenous bases exo- $N$ - $\{2-[N$-(4-azido-2,5-difluoro-3-chloropyridin-6-yl)-3-aminopropionyl]aminoethyl $\}$ deoxycytidinine (Fap-dC, Fig. 1A) was used as one as the model lesion. Extended (756 bp) Fap-dC-DNAs were obtained by adding the Fap-dCTP (up to 5, 10, 20, 40, 80, and $160 \mu \mathrm{M}$ ) to the reaction mixture during PCR (Table 2).

In addition to the $756 \mathrm{bp}$ Fap-dC-DNA containing different number of modified nucleotides and non-modified DNA of the same length and sequence, 137 bp nAnt-DNA (Fig 1B) was obtained.

Table 2. DNA obtained using the PCR and modified triphosphate.

\begin{tabular}{l|c}
\hline \multicolumn{1}{c|}{ DNA formal name } & $\begin{array}{c}\text { The concentration of Fap-dCTP in the } \\
\text { reaction mixture during PCR, } \mu \mathrm{M}\end{array}$ \\
\hline nm DNA & 0 \\
\hline 5-Fap-dC-DNA & 5 \\
\hline 10-Fap-dC-DNA & 10 \\
\hline 20-Fap-dC-DNA & 20 \\
\hline 40-Fap-dC-DNA & 40 \\
\hline 80-Fap-dC-DNA & 80 \\
\hline 160-Fap-dC-DNA & 160 \\
\hline
\end{tabular}

It was previously shown that nAnt is effectively removed by proteins of the NER system from model DNA in vitro $[12,19]$. The properties of nAnt-DNA as a NER substrate allow us to use it in our study for estimation of NER activity in vitro.

To assess the ability of model DNAs to suppress the activity of the NER system, the influence of such DNA on NER efficiency in vitro was studied. The efficiency of excision was estimated using extracts of human cervical cancer cells C33A. The incubation of $20 \mathrm{nM}$ 137 bp nAnt-DNA with cell extracts was carried out in [the] presence or absence of $3 \mathrm{nM}$ 756 bp competitive DNA. Non-modified DNA (nm DNA) or DNA containing the Fap-dC groups was used as a competitive DNA. The products of the specific excision obtained during the reaction were analyzed in $10 \%$ PAAG under denaturing conditions.

It was found that Fap-dC-containing DNA effectively suppresses the excision of bulky lesion from nAnt-containing DNA. The observed decrease in the relative efficiency of nAnt excision was 50-80\%, depending on the concentration of Fap-dCTP used in the synthesis of Fap-dC-DNA (Fig. 2). The greatest effect was observed in the experiment, where 40-FapdC-DNA was used as a competitor (Fig. 2A, line 6). Thus, this DNA structure can be considered as DNA with unrepairable damage, which most effectively inhibits the activity of the NER system.

To estimate the number of modified nucleotides included in 756 bp DNA during PCR, 40-Fap-dC-DNA was enzymatically hydrolyzed using "DNA Degradase" kit.

The resulting mixture of mononucleotides was analyzed by high performance liquid chromatography (HPLC) with chromatograph Milichrom A-02 and ProntoSIL-120-5-C18 AQ column. Modified Fap-dC nucleotide has sig- 

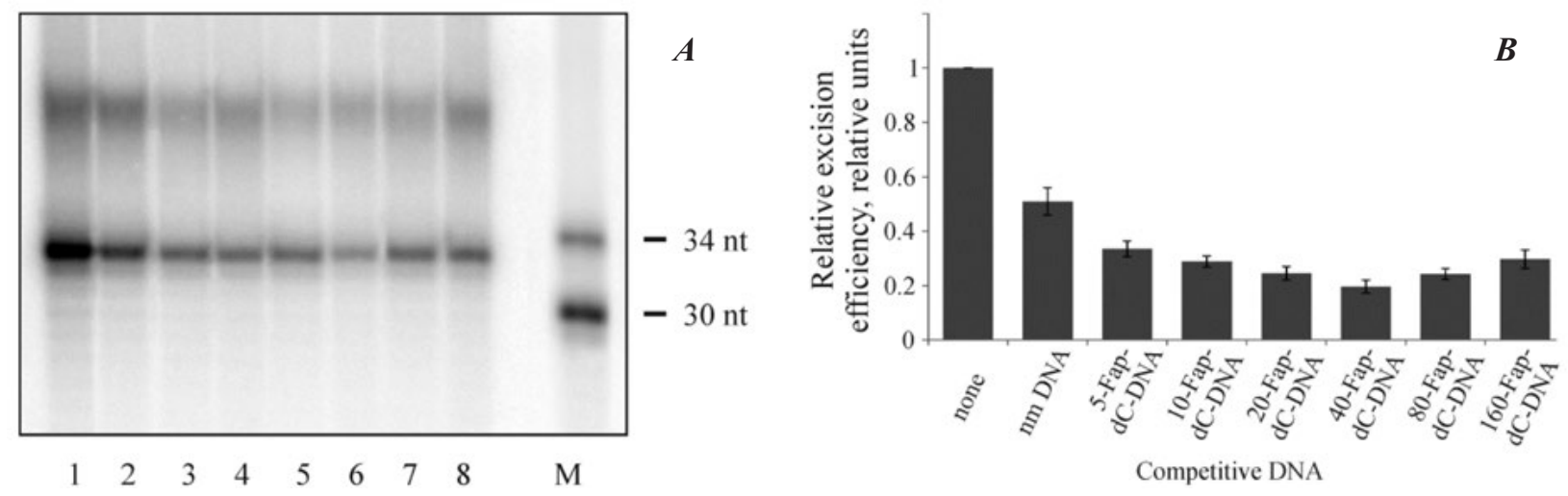

Fig. 2. $A-$ NER dual incision activity of C33A cell extract on nAnt-DNA, detected after 40 min incubation of model DNAs with cell extract. Reaction mixtures containing $20 \mathrm{nM}$ nAnt-DNA were incubated with C33A cells extract for $40 \mathrm{~min}$ at $30^{\circ} \mathrm{C}$ in the absence (lane 1) or presence of $3 \mathrm{nM}$ competitive DNA (lane 2 - non-modified duplex, lane 3 5-Fap-dC-DNA, lane 4 - 10-Fap-dC-DNA, lane 5 - 20-Fap-dC-DNA, lane 6-40-Fap-dC-DNA, lane 7 - 80-Fap-dCDNA, lane 8 - 160-Fap-dC-DNA). $M$ - markers of DNA length (nt, nucleotide), the lengths of the marker DNAs are given on the right. $B$ - The dependence of relative efficiency of the NER on the type of competitive DNA. Maximum product accumulation was taken as unit and was detected for nAnt-DNA incubated with cell extract for 40 min. Each experiment was performed three times, error bars indicate standard deviation of the relative NER efficiency at each experimental point.

nificantly higher retention time in the conditions used, so it was possible to calculate the corresponding peak area precisely. The peak areas corresponding to unmodified nucleotides were also calculated. Taking into account the values of extinction of nucleotides at the used wavelength, the amount of the modified nucleotide in the resulting mixture was estimated. It was found that hydrolyzate, and, consequently, the 40-Fap-dC-DNA contains approximately one modification per 20 non-modified nucleotides. The ratio of the modified to nonmodified triphosphates in the reaction mixture during PCR was also 1:20. Thus we can conclude that the modified $\mathrm{dC}$ is incorporated into the DNA during DNA synthesis catalyzed with Taq DNA polymerase with high efficiency matching the efficiency of unmodified dCTP incorporation. The results are consistent with the data obtained in the study of the substrate properties of Fap-dCTP in another incorporation reaction - the reaction catalyzed by DNA polymerase $\beta$ [21].

For the ability of model DNA to bind repair factors, not only the DNA sequence is crucial [24], but also the spatial organization of the DNA fragment in the damaged region [25-27].

According to our previous studies, Fap-dC lesion incorporated into DNA significantly affects the double-stranded structure of DNA. The long and flexible linker enables intercalation of the fluoroazido-pyridyl ring into the DNA helix. It results in stacking this residue with the purine rings of the opposite $\mathrm{dG}$, and no destabilization of the regular DNA duplex structure was found at the damaged site. The destabilized helical element is located on the $3^{\prime}$ side of the lesion [19]. Considering the 
previously obtained data and the calculated number of the modified groups into model DNA, we can assume the possible location of Fap-dC and the destabilization caused by lesions in Fap-dC-DNA. We assume that the ratio of modified to non-modified nucleotides into $756 \mathrm{bp}$ DNA under 1:20 allows the formation of several separate sites of DNA structure destabilization (Fig 3A). Such destabilization sites can be recognized by repair factors, such as XPC-HR23B, increasing their affinity for this type of structure. Being bound in unproductive complexes with Fap-dC-DNA, repair proteins can no longer participate in reparative processes. The copy number of NER proteins in the cell, and hence in cell extracts, is relatively small $[28,29]$. Therefore, even a small amount of the extended DNA is sufficient to significantly suppress the activity of NER.

An increase in the ratio of modified to nonmodified nucleotides in the DNA composition up to 1:20 leads to the appearance of the additional binding sites for repair factors, and hence to a more pronounced suppression of the NER activity. But a further increase in the number of modified groups leads to the interference of areas of the regular double-stranded structure destabilization (Fig. 3B). The question of the spatial organization of such DNA needs additional research. However, it can be assumed that significant distortions of the geometry and structure of the DNA duplex in this case interfere with their recognition as a NER substrate, and prevent the binding of repair factors with such model DNA.

The model DNAs with unrepairable lesions that can inhibit NER with high efficiency are of considerable interest. It is known that the main drugs used in the treatment of malignant tumors are cytostatics. Such drugs are able to disrupt the structure of the DNA in the cell, which leads to the activation of damage repair

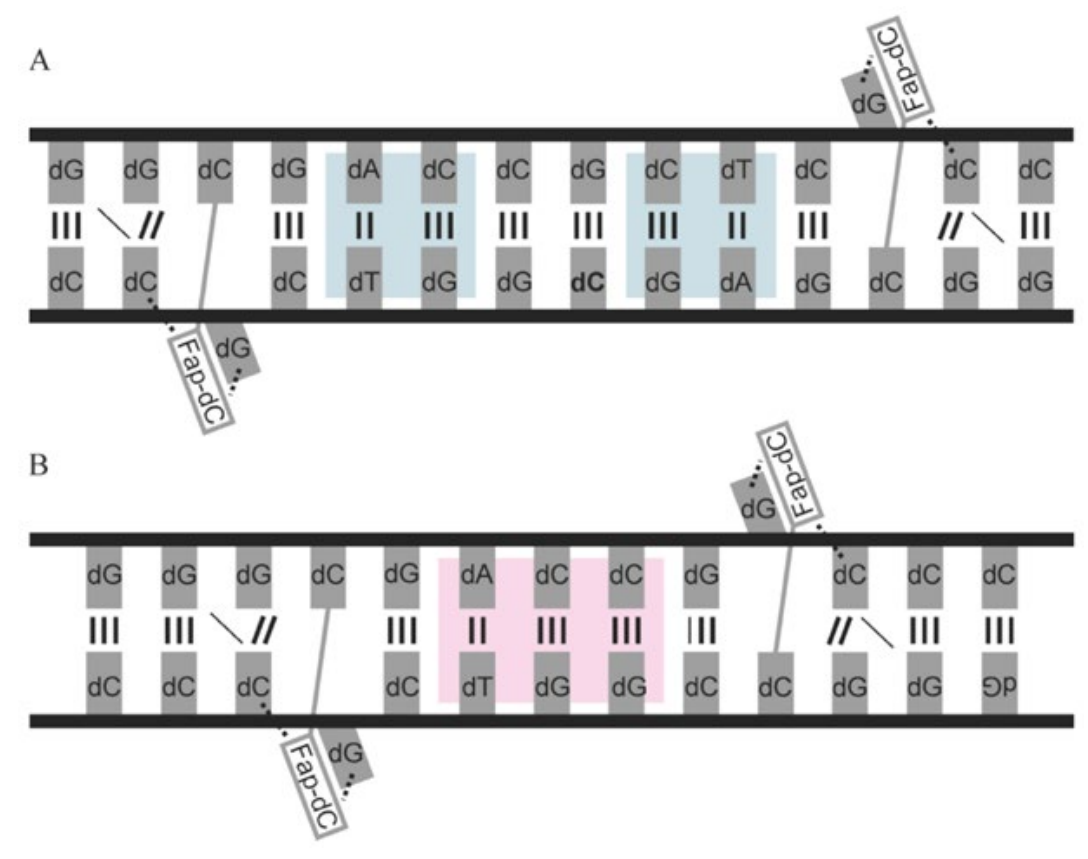

Fig. 3. Estimated patterns of duplex structure destabilization in Fap-dCDNA. The low ratio of modified to non-modified nucleotides presumably leads to the formation of separate regions of duplex structure destabilization (blue rectangles), while high ratio - to the formation of interfered regions (red rectangles). The most probable hydrogen bonds are also indicated: bold lines represent the hydrogen bonds occurring with more than $90 \%$ probability, thin lines - 50-90\%, dashed line $-10-50 \%$. 
systems. In case of adequate regimens of treatment and suitable cytostatic agent selection, the tumor cells are eliminated as a result of the induction of irreversible apoptosis or another mechanism of elimination. In this regard, the basis of successful treatment is the therapeutic "competence" of the drug used and the number of cytostatic molecules in the cell (the drug dose). However the activity of the NER system can eliminate the damage and reduce the therapeutic effect of anticancer drugs [30, 31]. The cytostatics with different mechanisms of action are used in the world practice. These are drugs that disrupt the DNA structure, and drugs that induce intrastrand or interstrand crosslinks. In all cases, if any of these lesions occur, a nucleotide excision repair system is induced as one of the earliest cell defense systems [32, 33]. If the damages have [been] detected and the repair process has occurred, the amount of damage per cell could decrease to [the] undertherapeutic levels. A cancer cell has significant genetic plasticity [34]. They are quite often highly resistant for cytostatic actions and survive, increasing the chance of relapse. Therefore, the DNA structures capable of effective inhibition of the activity of the NER system can be considered as potential anticancer drugs. The model DNA with bulky unrepairable adducts could inhibit the repair process by binding the key protein factors of the NER system. In this regard, the presence of model DNA with unreparable damage should increase the cytotoxicity of anticancer therapy based on the cytostatic agents, inducing inter- and intrastrand crosslinks into cell DNA, as well as the bulky lesions formation. Thus, the results of our investigation can potentially be used for design of DNA repair inhibitors and potentially in the applied research.

\section{Conclusions}

In the present report a new approach to the synthesis of DNA with unrepairable lesions was described. The obtained DNA structures were shown to inhibit the nucleotide excision repair in vitro. The DNA structure that inhibits the NER with the highest efficiency was selected for the further study and analyzed. The suggestion concerning the possible connection between the number of the modified nucleotides introduced in the model DNAs and their ability to inhibit the NER process was made. The data obtained in this paper will be useful for fundamental and medical research.

\section{Funding}

This study was supported by the Russian Science Foundation (project №17-74-10086); and Russian State funded budget project V1.57.1.2, 0309-2016-0001.

\section{REFERENCES}

1. Gillet LC, Schärer OD. Molecular mechanisms of mammalian global genome nucleotide excision repair. Chem Rev. 2006;106(2):253-76.

2. Sugasawa K. Regulation of damage recognition in mammalian global genomic nucleotide excision repair. Mutat Res. 2010;685(1-2):29-37.

3. Volker M, Moné MJ, Karmakar P, van Hoffen A, Schul W, Vermeulen W, Hoeijmakers JH, van Driel $R$, van Zeeland AA, Mullenders LH. Sequential assembly of the nucleotide excision repair factors in vivo. Mol Cell. 2001;8(1):213-24.

4. Sugasawa K, Okamoto T, Shimizu Y, Masutani C, Iwai $S$, Hanaoka $F$. A multistep damage recognition mechanism for global genomic nucleotide excision repair. Genes Dev. 2001;15(5):507-21. 
5. Hey T, Lipps G, Sugasawa K, Iwai S, Hanaoka F, Krauss $G$. The XPC-HR23B complex displays high affinity and specificity for damaged DNA in a trueequilibrium fluorescence assay. Biochemistry. 2002;41(21):6583-7.

6. Tapias A, Auriol J, Forget D, Enzlin JH, Schärer $O D$, Coin F, Coulombe B, Egly JM. Ordered conformational changes in damaged DNA induced by nucleotide excision repair factors. $J$ Biol Chem. 2004;279(18):19074-83.

7. DellaVecchia MJ, Croteau DL, Skorvaga M, Dezhurov SV, Lavrik OI, Van Houten B. Analyzing the handoff of DNA from UvrA to UvrB utilizing DNAprotein photoaffinity labeling. $J$ Biol Chem. 2004;279(43):45245-56.

8. Buterin T, Meyer C, Giese B, Naegeli H. DNA quality control by conformational readout on the undamaged strand of the double helix. Chem Biol. 2005;12(8):913-22.

9. Trego KS, Turchi JJ. Pre-steady-state binding of damaged DNA by XPC-hHR23B reveals a kinetic mechanism for damage discrimination. Biochemistry. 2006;45(6):1961-9.

10. Maltseva EA, Rechkunova NI, Petruseva IO, Silnikov $V N$, Vermeulen $W$, Lavrik OI. Interaction of nucleotide excision repair factors RPA and XPA with DNA containing bulky photoreactive groups imitating damages. Biochemistry (Mosc). 2006;71(3):270-8.

11. Petruseva IO, Tikhanovich IS, Chelobanov BP, Lavrik OI. RPA repair recognition of DNA containing pyrimidines bearing bulky adducts. $J \mathrm{Mol}$ Recognit. 2008;21(3):154-62.

12. Evdokimov A, Petruseva I, Tsidulko A, Koroleva L, Serpokrylova I, Silnikov V, Lavrik O. New synthetic substrates of mammalian nucleotide excision repair system. Nucleic Acids Res. 2013;41(12):e123.

13. Khodyreva SN, Lavrik OI. Photoaffinity labeling technique for studying DNA replication and DNA repair. Curr Med Chem. 2005;12(6):641-55.

14. Rechkunova NI, Lavrik OI. Nucleotide excision repair in higher eukaryotes: mechanism of primary damage recognition in global genome repair. Subcell Biochem. 2010;50:251-77.

15. Maltseva EA, Rechkunova NI, Gillet LC, Petruseva IO, Schärer OD, Lavrik OI. Crosslinking of the NER da- mage recognition proteins XPC-HR23B, XPA and RPA to photoreactive probes that mimic DNA damages. Biochim Biophys Acta. 2007;1770(5):781-9.

16. Krasikova YS, Rechkunova NI, Maltseva EA, Petruseva IO, Silnikov VN, Zatsepin TS, Oretskaya TS, Schärer OD, Lavrik OI. Interaction of nucleotide excision repair factors XPC-HR23B, XPA, and RPA with damaged DNA. Biochemistry (Mosc). 2008; 73(8):886-96.

17. Krasikova YS, Rechkunova NI, Maltseva EA, Petruseva IO, Lavrik OI. Localization of xeroderma pigmentosum group A protein and replication protein A on damaged DNA in nucleotide excision repair. Nucleic Acids Res. 2010;38(22):8083-94.

18. Evdokimov AN, Petruseva IO, Pestryakov PE, Lavrik OI. Photoactivated DNA analogs of substrates of the nucleotide excision repair system and their interaction with proteins of NER-competent extract of HeLa cells. Synthesis and application of long model DNA. Biochemistry (Mosc). 2011; 76(1):157-66.

19. Evdokimov AN, Tsidulko AY, Popov AV, Vorobiev YN, Lomzov AA, Koroleva LS, Silnikov VN, Petruseva IO, Lavrik OI. Structural basis for the recognition and processing of DNA containing bulky lesions by the mammalian nucleotide excision repair system. DNA Repair (Amst). 2018;61:86-98.

20. Evdokimov AN, Lavrik OI, Petruseva IO. Model DNA for investigation of mechanism of nucleotide excision repair. Biopolym Cell. 2014; 30(3): 167-83.

21. Dezhurov SV, Khodyreva SN, Plekhanova ES, Lavrik $O I$. A new highly efficient photoreactive analogue of dCTP. Synthesis, characterization, and application in photoaffinity modification of DNA binding proteins. Bioconjug Chem. 2005;16(1):215-22.

22. Petruseva IO, Tikhanovich IS, Maltseva EA, Safronov IV, Lavrik OI. Photoactivated DNA analogs of substrates of the nucleotide excision repair system and their interaction with proteins of NER-competent HeLa cell extract. Biochemistry (Mosc). 2009;74(5):491-501.

23. Manley JL, Fire A, Cano A, Sharp PA, Gefter ML. DNA-dependent transcription of adenovirus genes in a soluble whole-cell extract. Proc Natl Acad Sci U S A. 1980;77(7):3855-9. 
24. Kropachev K, Kolbanovskii M, Cai Y, Rodríguez F, Kolbanovskii A, Liu Y, Zhang L, Amin S, Patel D, Broyde S, Geacintov NE. The sequence dependence of human nucleotide excision repair efficiencies of benzo[a]pyrene-derived DNA lesions: insights into the structural factors that favor dual incisions. $J \mathrm{Mol}$ Biol. 2009;386(5):1193-203.

25. Krzeminski J, Kropachev K, Kolbanovskiy M, Reeves $D$, Kolbanovskiy A, Yun BH, Geacintov NE, Amin S, El-Bayoumy K. Inefficient nucleotide excision repair in human cell extracts of the $\mathrm{N}$ (deoxyguanosin-8-yl)-6-aminochrysene and 5-(deoxyguanosin-N(2)-yl)-6-aminochrysene adducts derived from 6-nitrochrysene. Chem Res Toxicol. 2011;24(1):65-72.

26. Ding S, Kropachev K, Cai Y, Kolbanovskiy M, Durandina $S A$, Liu Z, Shafirovich V, Broyde S, Geacintov $N E$. Structural, energetic and dynamic properties of guanine(C8)-thymine(N3) cross-links in DNA provide insights on susceptibility to nucleotide excision repair. Nucleic Acids Res. 2012;40(6):2506-17.

27. Mu H, Kropachev K, Wang L, Zhang L, Kolbanovskiy A, Kolbanovskiy M, Geacintov NE, Broyde $S$. Nucleotide excision repair of 2-acetylaminofluorene- and 2-aminofluorene-(C8)-guanine adducts: molecular dynamics simulations elucidate how lesion structure and base sequence context impact repair efficiencies. Nucleic Acids Res. 2012;40(19): 9675-90.

28. Araújo SJ, Nigg EA, Wood RD. Strong functional interactions of TFIIH with XPC and XPG in human DNA nucleotide excision repair, without a preassembled repairosome. Mol Cell Biol. 2001;21(7):2281-91.

29. Mu D, Hsu DS, Sancar A. Reaction mechanism of human DNA repair excision nuclease. $J$ Biol Chem. 1996;271(14):8285-94.

30. RRocha JC, Busatto FF, Guecheva TN, Saffi J. Role of nucleotide excision repair proteins in response to DNA damage induced by topoisomerase II inhibitors. Mutat Res Rev Mutat Res. 2016;768:68-77.

31. Bowden NA. Nucleotide excision repair: why is it not used to predict response to platinum-based chemotherapy? Cancer Lett. 2014;346(2):163-71.

32. Clauson C, Schärer OD, Niedernhofer L. Advances in understanding the complex mechanisms of DNA interstrand cross-link repair. Cold Spring Harb Perspect Biol. 2013;5(10):a012732.

33. De Silva IU, McHugh PJ, Clingen PH, Hartley JA. Defining the roles of nucleotide excision repair and recombination in the repair of DNA interstrand cross-links in mammalian cells. Mol Cell Biol. 2000;20(21):7980-90.

34. Sarasin A, Dessen P. DNA repair pathways and human metastatic malignant melanoma. Curr $\mathrm{Mol}$ Med. 2010;10(4):413-8.

\section{Нерепаровані аналоги субстатті ексцизійної репарації нуклеотидів і їх застосування для придушення активності цієї системи}

О. О. Попов, А. М. Свдокимов, Н. В. Лук'янчикова, І. О. Петрусева, О. І. Лаврик

У наших попередніх дослідженнях було показано, що ДНК з об'ємним похідним Fap-dC є складнорепарованим субстратом для системи ексцизійної репарації нуклеотидів (Ерн). З'єднання такого типу можуть становити особливий інтерес як можливі селективні інгібітори системи Ерн, значно знижуючи ефективність репарації ДНК шляхом зв'язування білкових чинників, залучених до даного процесу. Цей підхід може бути потенційно корисний для підвищення ефективності хіміотерапії. Мета. Дане дослідження спрямоване на пошук ДНК-структур, що містять множинні об'ємні аддукти, які з найбільшою ефективністю можуть пригнічувати активність системи. Методи. Ферментативний синтез ДНК, ПЛР, приготування Ерн-компетентних клітинних екстрактів, реакція вирізання, що каталізується білками Ерн in vitro, ВЕРХ. Результати. Проведено підбір умов синтезу протяжних модельних ДНК $з$ множинним включенням нерепарованого пошкодження Fap-dC. Отримано ряд ДНК-структур, що містить в своєму складі різну кількість модифікованих ланок. Показано, що всі отримані ДНК пригнічують активність системи Ерн in vitro. Обрана ДНКструктура, яка пригнічує NER найбільш високою ефективністю. Висновки. Модельні ДНК з нерепарованими ушкодженнями, здатні високою ефективністю пригнічувати NER, можуть розглядатися в якості інгібіторів системи Ерн. Виявлені в даній роботі закономірності потенційно можуть бути використані для 
проведення як фундаментальних, так і прикладних досліджень.

К л юч о в і с л о в а: репарація, Ексцизійна репарація нуклеотидів, нерепаріруемие пошкодження ДНК, модельні ДНК-субстрати

\section{Нерепарируемые аналоги субстатов эксцизионной репарации нуклеотидов и их применение для подавления активности этой системы}

А. А. Попов, А. Н. Евдокимов, Н. В. Лукьянчикова, И. О. Петрусева, О. И. Лаврик

В наших предыдущих исследованиях было показано, что ДНК с объемным производным Fap-dC является труднорепарируемым субстратом для системы эксцизионной репарации нуклеотидов (ЭРН). Соединения такого типа могут представлять особый интерес как возможные селективные ингибиторы системы ЭРН, значительно снижая эффективность репарации ДНК путем связывания белковых факторов, вовлеченных в этот процесс. Этот подход может быть потенциально полезен для повышения эффективности химиотерапии. Цель. Текущее исследование направлено на поиск ДНК-структур, содержащих множественные объемные аддукты, которые с наибольшей эффективностью мо- гут подавлять активность системы. Методы: ферментативный синтез ДНК, ПЦР, приготовление ЭРНкомпетентных клеточных экстрактов, реакция вырезания, катализируемая белками ЭРН in vitro, ВЭЖХ. Результаты: был проведен подбор условий синтеза протяженных модельных ДНК с множественным включением нерепарируемого повреждения Fap-dC. Получен ряд ДНК-структур, содержащий в своем составе различное количество модифицированных звеньев. Было показано, что все полученные ДНК подавляют активность системы ЭРН in vitro. Была выбрана ДНК-структура, которая ингибирует NER наиболее высокой эффективностью. Выводы: модельные ДНК с нерепарируемыми повреждениями, способные высокой эффективностью подавлять NER, могут рассматриваться в качестве ингибиторов системы ЭРН. Обнаруженные в настоящей работе закономерности потенциально могут быть использованы для проведения не только фундаментальных, но и прикладных исследований.

Ключев ы е сл ов а: эксцезионная репарация нуклеотидов, нерепарируемые повреждения ДНК, модельные ДНК-субстраты.

Received 03.01.2019 